\title{
Single-inhaler Triple vs Single-inhaler Dual Therapy in Patients with Chronic Obstructive Pulmonary Disease: A Meta-analysis of Randomized Control Trials
}

\author{
Huanyu Long \\ Beijing Hospital \\ Hongxuan Xu \\ Beijing Hospital \\ Jean-Paul Janssens \\ Geneva University Hospitals: Hopitaux Universitaires Geneve \\ Yanfei Guo ( $\square$ yanfeiguo2003@126.com ) \\ Beijing Hospital https://orcid.org/0000-0002-0437-3766
}

\section{Research}

Keywords: COPD, triple therapy, mortality, meta-analysis

Posted Date: February 10th, 2021

DOI: https://doi.org/10.21203/rs.3.rs-183072/v1

License: (9) (7) This work is licensed under a Creative Commons Attribution 4.0 International License. Read Full License

Version of Record: A version of this preprint was published at Respiratory Research on July 23rd, 2021. See the published version at https://doi.org/10.1186/s12931-021-01794-w. 


\begin{abstract}
BACKGROUND: A meta-analysis was performed to compare the efficacy and safety of single-inhaler triple therapy combining long-acting beta2-agonist (LABA), long-acting muscarinic antagonist (LAMA), and inhaled corticosteroids (ICS) versus single-inhaler dual therapy (ICS/LABA and LABA/LAMA) in patients with chronic obstructive pulmonary disease (COPD).
\end{abstract}

METHODS: We used the following search terms in PubMed, MEDLINE (OvidSP), EMBASE and Cochrane Library databases to investigate the effect of singleinhaler triple therapy in COPD. The primary end points were the effect of single-inhaler triple therapy on all-cause mortality, risk of acute exacerbation of COPD (AECOPD), and some safety endpoints, compared with single-inhaler dual therapy. Cochrane Collaboration's tool was used to assess quality of each randomized trial and risk of bias.

RESULTS: A total of 25,171 patients suffering from COPD were recruited for the 6 studies. This meta-analysis indicated that single-inhaler triple therapy resulted in a significantly lower rate of all-cause mortality than single-inhaler dual therapy (risk ratio, 0.83; 95\% $\mathrm{Cl} 0.71-0.98$ ). Single-inhaler triple therapy reduced the risk of exacerbation (rate ratio, $0.78 ; 95 \% \mathrm{Cl} 0.73-0.83$ ), prolonged time to first exacerbation (hazard ratio, $0.86 ; 95 \% \mathrm{Cl} 0.84-0.89$ ), improved trough FEV1 (mean difference, 81.35 ml; 95\% Cl 45.6-117.06) and St George Respiratory Questionnaire (SGRQ) Score (mean difference, -1.48; 95\% Cl-1.75--1.22) vs. single-inhaler dual therapy. Risk of pneumonia was however significantly higher with ICS/LAMA/LABA than with LABA/LAMA (risk ratio, 1.25; 95\% Cl 1.041.50).

CONCLUSIONS: This meta-analysis suggests that single-inhaler triple therapy is effective in reducing the risk of moderate or severe exacerbations and death of any causes in COPD patients, compared with single-inhaler dual therapy. However, risk of pneumonia is higher with ICS/LAMA/LABA combination than with dual therapy of LABA/LAMA.

TRIAL REGISTRY: ClinicalTrials.gov; No.: CRD42020186726; URL: www.clinicaltrials.gov.

\title{
Introduction
}

Chronic obstructive pulmonary disease (COPD) is a worldwide public health challenge with a high prevalence, morbidity, and mortality [1] [2]. Regular administration of inhaled drugs including long-acting beta2-agonists (LABA), long-acting muscarinic antagonists (LAMA), and inhaled corticosteroids (ICS) is widely acknowledged as a major component of treatment of COPD [3].

The 2020 Global Initiative for Chronic Obstructive Lung Disease (GOLD) guidelines recommend that combining LABA, LAMA and ICS (triple therapy) be considered for the most severe COPD patients. [3] Triple therapy may be delivered via multiple separate inhalers (in open combination) [4] [5] [6] or within a single inhaler (in fixed-dose combination).[7] [8] [9] [10] In the real-world, triple therapy is still frequently administered via multiple devices,[11] which may lead to an incorrect inhalation technique in a significant proportion of patients. [12] Single-inhaler therapy may be of benefit in patients with COPD, by decreasing inhaler errors, improving adherence rates, and decreasing healthcare costs.[13] [14] [15] Single-inhaler triple therapy is expected to be soon widely available. We therefore performed this systematic review to determine the effect of single-inhaler triple therapy on the risk of exacerbation, mortality, and other relevant outcomes in patients with COPD.

\section{Methods}

\section{Search strategy}

This meta-analysis followed the guidance of the Preferred Reporting Items for Systematic Reviews and Meta-analyses (PRISMA) statement. [16] This study was prospectively registered in Prospero (CRD42020186726).

We used the following search terms in PubMed, MEDLINE (OvidSP), EMBASE and Cochrane Library databases to identify studies published up to August 1 , 2020: "chronic obstructive pulmonary disease", "triple", “long acting antimuscarinics", "long-acting beta-2 agonists" or "inhaled corticosteroids". The "Patients, Intervention, Control, and Outcome" (PICO) framework was utilized to improve the relevance of search results, as previously described.[17] Patients included were "Stable COPD"; the intervention was "single-inhaler triple therapy (LABA/LAMA/ICS)", control arm was "single-inhaler dual therapy (ICS/LABA or LABA/LAMA)", and outcomes were "death, risk of moderate or severe exacerbations, time to exacerbation, lung function, health related quality of life and safety profile".

\section{Study selection and data extraction}

Data were independently extracted by two reviewers, and any difference in opinion about eligibility was resolved through consensus. We collected information from each randomized trial about study features (title, year, author, study design and duration of follow-up, etc.), participants (mean age, sex, current smoker, etc.), interventions (control therapy and inhaler type, intervention therapy and inhaler type), and outcomes (death, moderate or severe exacerbations, the first time to exacerbation, mean change in FEV1, SGRQ (St George Respiratory Questionnaire) score, adverse events, serious adverse events, cardiovascular events and pneumonia events). When data could not be extracted from the published reports, we extrapolated from the supplementary material.

\section{Quality score and risk of bias assessment}

Cochrane Collaboration's tool was used to assess quality of each randomized trial and risk of bias. We analyzed included trials for allocation concealment, random sequence generation, blinding of outcome assessment, incomplete outcome data, selective reporting, blinding of participants and personnel, and other biases. 


\section{Data synthesis and statistical analysis}

We used Revman 5.3 software for all statistical analyses. The degree of heterogeneity among RCTs was evaluated with the Q test and $\mathrm{I}^{2}$ statistic. When $\mathrm{I}^{2}$ values were $\geq 50 \%$, we considered this as representing significant heterogeneity, and applied a random effects model. We combined continuous data using Inverse-variance test for hazard ratio (HR), rate ratio (RR), and mean difference (MD) with $95 \%$ confidence intervals (95\% Cls) and combined dichotomous data using Mantel-Haenszel test for risk ratio (RR) with 95\% confidence interval (95\% Cls).

\section{Results}

We obtained 913 articles from our initial search, and 36 additional articles were identified through manual searches. At the end of the selection process, 6 RCTs[7] [8] [9] [10] [18] [19]were included in this meta-analysis. The flow diagram of the study selection process is shown in Fig. 1. A total of 25,171 COPD patients had been recruited for these 6 studies: 11,420 patients were treated with single-inhaler triple therapy, and 13,751 patients were treated with singleinhaler dual therapy (5,588 patients received LABA/LAMA and 8,163 patients received ICS/LABA). The summary of relevant studies and patient characteristics are provided in Table 1 and Table 2. Risk of bias for studies included is detailed in Fig. 2. 
Table 1

Details of included RCTs

\begin{tabular}{|c|c|c|c|c|c|c|c|}
\hline Number & Study & Study design & $\begin{array}{l}\text { Duration } \\
\text { of } \\
\text { follow- } \\
\text { up }\end{array}$ & Inclusion criteria & $\begin{array}{l}\text { Exclusion } \\
\text { criteria }\end{array}$ & $\begin{array}{l}\text { Drugs, } \\
\text { Doses }(\mu \mathrm{g}), \\
\text { Regimen, } \\
\text { Device }\end{array}$ & $\begin{array}{l}\text { No of } \\
\text { patients }\end{array}$ \\
\hline \multirow[t]{4}{*}{1} & \multirow{4}{*}{$\begin{array}{l}\text { TRILOGY } \\
\text { Singh,2016 }\end{array}$} & \multirow{4}{*}{$\begin{array}{l}\text { A randomized, } \\
\text { parallel group, } \\
\text { double-blind, } \\
\text { active- } \\
\text { controlled } \\
\text { study }\end{array}$} & \multirow[t]{4}{*}{ 52weeks } & \multirow{4}{*}{$\begin{array}{l}\text { FEV1 }<50 \% \text {; moderate or severe COPD } \\
\text { exacerbation in the previous } 12 \text { months } \geq 1 \text {; } \\
\text { CAT score } \geq 10 \text {, BDI score } \leq 10 \text {. }\end{array}$} & \multirow{4}{*}{$\begin{array}{l}\text { Asthma, } \\
\text { history of } \\
\text { allergic } \\
\text { rhinitis; } \\
\text { clinically } \\
\text { significant } \\
\text { cardiovascular } \\
\text { conditions. }\end{array}$} & BDP/FOR/GLY & 687 \\
\hline & & & & & & bid MDI & \\
\hline & & & & & & $\begin{array}{l}\text { BDP/FOR } \\
(100 / 6)\end{array}$ & 680 \\
\hline & & & & & & bid MDI & \\
\hline \multirow[t]{4}{*}{2} & \multirow{4}{*}{$\begin{array}{l}\text { FULFIL } \\
\text { Lipson,2017 }\end{array}$} & \multirow{4}{*}{$\begin{array}{l}\text { A phase 3, } \\
\text { randomized, } \\
\text { double-blind, } \\
\text { double-dummy, } \\
\text { parallel-group, } \\
\text { multicenter } \\
\text { study }\end{array}$} & \multirow[t]{4}{*}{ 24weeks } & \multirow{4}{*}{$\begin{array}{l}\text { FEV } 1<50 \% \text { and CAT score } \geq 10 \text { or } 50 \% \\
\leq \text { FEV } 1<80 \% \text { and CAT score } \geq 10 ; \text { moderate } \\
\text { COPD exacerbation in the previous } 12 \\
\text { months } \geq 2 \text { or severe COPD exacerbation in } \\
\text { the previous } 12 \text { months } \geq 1 \text {. }\end{array}$} & \multirow{4}{*}{$\begin{array}{l}\text { Asthma, } \\
\text { unresolved } \\
\text { pneumonia, } \\
\text { severe COPD } \\
\text { exacerbation. }\end{array}$} & FF/UMEC/VI & 911 \\
\hline & & & & & & od DPI & \\
\hline & & & & & & $\begin{array}{l}\text { BUD/FOR } \\
(400 / 12)\end{array}$ & 899 \\
\hline & & & & & & bid DPI & \\
\hline \multirow[t]{6}{*}{3} & \multirow{6}{*}{$\begin{array}{l}\text { IMPACT } \\
\text { Lipson,2018 }\end{array}$} & \multirow{6}{*}{$\begin{array}{l}\text { A phase 3, } \\
\text { randomized, } \\
\text { double-blind, } \\
\text { parallel-group, } \\
\text { multicenter trial }\end{array}$} & \multirow[t]{6}{*}{52 weeks } & \multirow{6}{*}{$\begin{array}{l}\text { FEV } 1<50 \% \text { and moderate or severe COPD } \\
\text { exacerbation in the previous } 12 \text { months } \geq 1 \\
\text { or } 50 \% \leq \mathrm{FEV} 1<80 \% \text { and moderate COPD } \\
\text { exacerbation in the previous } 12 \text { months } \geq 2 \\
\text { or severe COPD exacerbation in the previous } \\
12 \text { months } \geq 1 \text {. }\end{array}$} & \multirow[t]{6}{*}{ NA } & $\begin{array}{l}\text { FF/UMEC/VI } \\
(100 / 625 / 25)\end{array}$ & 4151 \\
\hline & & & & & & & \\
\hline & & & & & & $\begin{array}{l}\text { FF/VI } \\
(100 / 25)\end{array}$ & 4134 \\
\hline & & & & & & od DPI & \\
\hline & & & & & & $\begin{array}{l}\text { UMEC/VI } \\
(62.5 / 25)\end{array}$ & 2070 \\
\hline & & & & & & od DPI & \\
\hline \multirow[t]{6}{*}{4} & \multirow{6}{*}{$\begin{array}{l}\text { KRONOS } \\
\text { Ferguson,2018 }\end{array}$} & \multirow{6}{*}{$\begin{array}{l}\text { A randomized, } \\
\text { double-blind, } \\
\text { parallel-group, } \\
\text { phase } 3 \\
\text { randomized } \\
\text { controlled trial }\end{array}$} & \multirow[t]{6}{*}{ 24weeks } & \multirow[t]{6}{*}{$25 \% \leq \mathrm{FEV} 1<80 \%$;CAT score $\geq 10$} & \multirow{6}{*}{$\begin{array}{l}\text { Asthma, } \\
\text { diagnosis of } \\
\text { any } \\
\text { respiratory } \\
\text { disease. }\end{array}$} & $\begin{array}{l}\text { BUD/GLY/FOR } \\
(320 / 18 / 9.6)\end{array}$ & 639 \\
\hline & & & & & & bid MDI & \\
\hline & & & & & & $\begin{array}{l}\text { GLY/FOR } \\
(18 / 9.6)\end{array}$ & 625 \\
\hline & & & & & & bid MDI & \\
\hline & & & & & & $\begin{array}{l}\text { BUD/FOR } \\
(320 / 9.6)\end{array}$ & 314 \\
\hline & & & & & & bid MDI & \\
\hline \multirow[t]{4}{*}{5} & \multirow{4}{*}{$\begin{array}{l}\text { TRIBUTE } \\
\text { Papi,2018 }\end{array}$} & \multirow{4}{*}{$\begin{array}{l}\text { A randomized, } \\
\text { parallel-group, } \\
\text { double-blind, } \\
\text { double-dummy, } \\
\text { active- } \\
\text { controlled } \\
\text { phase } 3 \text { b study }\end{array}$} & \multirow[t]{4}{*}{52 weeks } & \multirow{4}{*}{$\begin{array}{l}\text { FEV } 1<50 \% \text {; a moderate or severe COPD } \\
\text { exacerbation in the previous } 12 \text { months } \geq 1 \text {; } \\
\text { CAT score } \geq 10 \text {. }\end{array}$} & $\begin{array}{l}\text { Asthma; } \\
\text { clinically }\end{array}$ & $\begin{array}{l}\text { BDP/FOR/GLY } \\
(100 / 6 / 10)\end{array}$ & 764 \\
\hline & & & & & significant & bid MDI & \\
\hline & & & & & & $\begin{array}{l}\text { IND/GLY } \\
(85 / 43)\end{array}$ & 768 \\
\hline & & & & & & od DPI & \\
\hline 6 & ETHOS & A phase 3, & 52 weeks & 40 years $\leq$ age $\leq 80$ years, CAT $\geq 10,25 \%$ & $\begin{array}{l}\text { Current } \\
\text { diagnosis of }\end{array}$ & BUD/GLY/FOR & 2144 \\
\hline & Rabe,2020 & $\begin{array}{l}\text { double-blind, } \\
\text { parallel-group, }\end{array}$ & & $\begin{array}{l}\text { years, FEV } 1<50 \% \text { and moderate or severe } \\
\text { COPD exacerbation in the previous } 12\end{array}$ & asthma. & & \\
\hline & & & & $\begin{array}{l}\text { COPD exacerbation in the previous } 12 \\
\text { months } \geq 2 \text { or severe COPD exacerbation in } \\
\text { the previous } 12 \text { months } \geq 1 \text {. }\end{array}$ & & $\begin{array}{l}\text { BUD/GLY/FOR } \\
(160 / 18 / 9.6) \\
\text { bid MDI }\end{array}$ & 2124 \\
\hline & & & & & & $\begin{array}{l}\text { BUD/FOR } \\
(320 / 9.6)\end{array}$ & 2136 \\
\hline & & & & & & bid MDI & \\
\hline & & & & & & $\begin{array}{l}\text { GLY/FOR } \\
(18 / 9.6)\end{array}$ & 2125 \\
\hline & & & & & & bid MDI & \\
\hline
\end{tabular}


Page 5/13 
Table 2

Patient baseline characteristics

\begin{tabular}{|c|c|c|c|c|c|c|c|c|c|c|}
\hline Number & Study & $\begin{array}{l}\text { Drugs, } \\
\text { Doses( } \mu g), \\
\text { Regimen, } \\
\text { Device }\end{array}$ & $\begin{array}{l}\text { No of } \\
\text { patients }\end{array}$ & $\begin{array}{l}\text { Age } \\
\text { means } \\
(\mathrm{SD})\end{array}$ & $\begin{array}{l}\text { Male } \\
(\%)\end{array}$ & $\begin{array}{l}\text { Current } \\
\text { smoker } \\
(\%)\end{array}$ & $\begin{array}{l}\text { Postbronchodilator } \\
\text { FEV1, \% Predicted } \\
\text { (SD) }\end{array}$ & $\begin{array}{l}\text { Moderate/severe } \\
\text { COPD } \\
\text { exacerbation in } \\
\text { previous } 12 \\
\text { months, } \mathrm{n}(\%) 0\end{array}$ & $\begin{array}{l}\text { Moderate/severe } \\
\text { COPD } \\
\text { exacerbation in } \\
\text { previous } 12 \\
\text { months, } \mathrm{n}(\%) 1\end{array}$ & $\begin{array}{l}1 \\
\mathbf{c} \\
\mathbf{f} \\
\mathbf{r}\end{array}$ \\
\hline \multirow[t]{4}{*}{1} & \multirow{4}{*}{$\begin{array}{l}\text { TRILOGY } \\
\text { Singh,2016 }\end{array}$} & $\begin{array}{l}\text { BDP/FOR/GLY } \\
(100 / 6 / 12.5)\end{array}$ & 687 & 63.3(7.9) & 74 & 47 & $36.9(8.4)$ & NA & NA & $\Lambda$ \\
\hline & & bid MDI & & & & & & & & \\
\hline & & $\begin{array}{l}\text { BDP/FOR } \\
(100 / 6)\end{array}$ & 680 & $63.8(8.2)$ & 77 & 47 & $36.2(8.6)$ & NA & NA & $\uparrow$ \\
\hline & & bid MDI & & & & & & & & \\
\hline \multirow[t]{4}{*}{2} & \multirow{4}{*}{$\begin{array}{l}\text { FULFIL } \\
\text { Lipson,2017 }\end{array}$} & $\begin{array}{l}\text { FF/UMEC/VI } \\
(100 / 625 / 25)\end{array}$ & 911 & $64.2(8.56)$ & 74 & 44 & $45.5(12.97)$ & 34 & 28 & 3 \\
\hline & & od DPI & & & & & & & & \\
\hline & & $\begin{array}{l}\text { BUD/FOR } \\
(400 / 12)\end{array}$ & 899 & 63.7(8.71) & 74 & 44 & $45.1(13.64)$ & 35 & 28 & 3 \\
\hline & & bid DPI & & & & & & & & \\
\hline \multirow[t]{6}{*}{3} & \multirow{6}{*}{$\begin{array}{l}\text { IMPACT } \\
\text { Lipson,2018 }\end{array}$} & $\mathrm{FF} / \mathrm{UMEC} / \mathrm{VI}$ & 4151 & $65.3(8.2)$ & 67 & 35 & $45.7(15.0)$ & $<1$ & 45 & 5 \\
\hline & & od DPI & & & & & & & & \\
\hline & & $\begin{array}{l}\text { FF/VI } \\
(100 / 25)\end{array}$ & 4134 & $65.3(8.3)$ & 66 & 34 & $45.5(14.8)$ & $<1$ & 46 & 5 \\
\hline & & od DPI & & & & & & & & \\
\hline & & $\begin{array}{l}\text { UMEC/VI } \\
(62.5 / 25)\end{array}$ & 2070 & $65.2(8.3)$ & 66 & 35 & $45.4(14.7)$ & $<1$ & 45 & 5 \\
\hline & & od DPI & & & & & & & & \\
\hline \multirow[t]{6}{*}{4} & \multirow{6}{*}{$\begin{array}{l}\text { KRONOS } \\
\text { Ferguson,2018 }\end{array}$} & $\begin{array}{l}\text { BUD/GLY/FOR } \\
(320 / 18 / 9.6)\end{array}$ & 639 & $64.9(7.8)$ & 72 & 40.1 & $50.2(14.3)$ & 73.4 & 19.6 & 7 \\
\hline & & bid MDI & & & & & & & & \\
\hline & & $\begin{array}{l}\text { GLY/FOR } \\
(18 / 9.6)\end{array}$ & 625 & $65.1(7.7)$ & 68.8 & 41.1 & $50.2(13.8)$ & 75.7 & 17.3 & 7 \\
\hline & & bid MDI & & & & & & & & \\
\hline & & $\begin{array}{l}\text { BUD/FOR } \\
(320 / 9.6)\end{array}$ & 314 & $65.2(7.2)$ & 71.3 & 36.6 & $50(14)$ & 74.8 & 19.4 & 5 \\
\hline & & bid MDI & & & & & & & & \\
\hline \multirow[t]{4}{*}{5} & \multirow{4}{*}{$\begin{array}{l}\text { TRIBUTE } \\
\text { Papi,2018 }\end{array}$} & $\begin{array}{l}\text { BDP/FOR/GLY } \\
(100 / 6 / 10)\end{array}$ & 764 & $64.4(7.7)$ & 72 & 46 & $36.4(8.0)$ & NA & 80 & 2 \\
\hline & & bid MDI & & & & & & & & \\
\hline & & $\begin{array}{l}\text { IND/GLY } \\
(85 / 43)\end{array}$ & 768 & $64.5(7.7)$ & 72 & 43 & $36.4(8.1)$ & NA & 82 & 1 \\
\hline & & od DPI & & & & & & & & \\
\hline \multirow[t]{8}{*}{6} & \multirow{8}{*}{$\begin{array}{l}\text { ETHOS } \\
\text { Rabe,2020 }\end{array}$} & $\begin{array}{l}\text { BUD/GLY/FOR } \\
(320 / 18 / 9.6)\end{array}$ & 2144 & $64.6(7.6)$ & 59 & 42.6 & $43.6(10.3)$ & 0.1 & 44 & 5 \\
\hline & & bid MDI & & & & & & & & \\
\hline & & $\begin{array}{l}\text { BUD/GLY/FOR } \\
(160 / 18 / 9.6)\end{array}$ & 2124 & $64.6(7.6)$ & 61.2 & 40.8 & $43.1(10.4)$ & 0.1 & 43.9 & 5 \\
\hline & & bid MDI & & & & & & & & \\
\hline & & $\begin{array}{l}\text { BUD/FOR } \\
(320 / 9.6)\end{array}$ & 2136 & $64.6(7.6)$ & 60 & 40.5 & $43.4(10.4)$ & 0.1 & 42.8 & 5 \\
\hline & & bid MDI & & & & & & & & \\
\hline & & $\begin{array}{l}\text { GLY/FOR } \\
(18 / 9.6)\end{array}$ & 2125 & $64.8(7.6)$ & 58.7 & 40.4 & $43.5(10.2)$ & 0.1 & 42.8 & 5 \\
\hline & & bid MDI & & & & & & & & \\
\hline
\end{tabular}




\begin{tabular}{|c|c|c|c|c|c|c|c|c|c|}
\hline Number & Study & $\begin{array}{l}\text { Drugs, } \\
\text { Doses }(\mu g), \\
\text { Regimen, } \\
\text { Device }\end{array}$ & $\begin{array}{l}\text { No of } \\
\text { patients }\end{array}$ & $\begin{array}{l}\text { Age } \\
\text { means } \\
(\mathrm{SD})\end{array}$ & $\begin{array}{l}\text { Male } \\
(\%)\end{array}$ & $\begin{array}{l}\text { Current } \\
\text { smoker } \\
(\%)\end{array}$ & $\begin{array}{l}\text { Postbronchodilator } \\
\text { FEV1, \% Predicted } \\
\text { (SD) }\end{array}$ & $\begin{array}{l}\text { Moderate/severe } \\
\text { COPD } \\
\text { exacerbation in } \\
\text { previous } 12 \\
\text { months, } n(\%) 0\end{array}$ & $\begin{array}{l}\text { Moderate/severe } \\
\text { COPD } \\
\text { exacerbation in } \\
\text { previous } 12 \\
\text { months, } n \text { (\%) } 1\end{array}$ \\
\hline
\end{tabular}

BDP/FOR/GLY: beclomethasone dipropionate/formoterol fumarate/glycopyrronium bromide;

BUD/GLY/FOR: budesonide/glycopyrronium bromide/formoterol fumarate;

FF/UMEC/VI: fluticasone furoate/umeclidinium/vilanterol:

BDP/FOR: beclomethasone dipropionate/formoterol fumarate;

BUD/FOR: budesonide/formoterol fumarate;

UMEC/VI: umeclidinium bromide/vilanterol;

GLY/FOR: glycopyrronium bromide/formoterol fumarate;

IND/GLY: indacaterol/glycopyrronium bromide.

OD: once daily;

BID: twice daily;

MDI: metered-dose inhaler formulation;

DPI: dry powder inhaler formulation;

FEV1: forced expiratory volume in 1 second;

BDI: Baseline Dyspnea Index;

CAT: COPD assessment test.

\section{Efficacy endpoints}

This meta-analysis suggested that single-inhaler triple therapy was associated with a lower all-cause mortality than single-inhaler dual therapy (risk ratio, 0.83 ; $\left.95 \% \mathrm{Cl} 0.71-0.98 ; P=0.03 ; I^{2}=0 \%\right)$. Compared with patients receiving LABA/LAMA, those on ICS/LAMA/LABA had a significantly lower mortality rate (RR, 0.70 ; 95\% Cl 0.56-0.88; $\left.P \otimes 0.01 ; I^{2}=0 \%\right) ;$ no significant difference was found however between ICS/LAMA/LABA and ICS/ LABA (RR, 1.00; 95\% CI 0.79-1.26; Pख0.05; $\mathrm{I}^{2}=0 \%$ ) (Figure 3$)$.

Use of single-inhaler triple therapy was associated with a significant decrease in risk of moderate or severe COPD exacerbations, compared to single-inhaler dual therapy (rate radio, $0.78 ; 95 \% \mathrm{Cl} 0.73-0.83 ; P<0.01 ; I^{2}=70 \%$ ). This was also the case when comparing specifically ICS/LAMA/LABA vs. ICS/LABA (RR, 0.85; 95\% Cl 0.81-0.88; $\left.P<0.01 ; I^{2}=1 \%\right)$ and comparing ICS/LAMA/LABA vs. LABA/LAMA (RR, 0.74; $\left.95 \% \mathrm{Cl} 0.67-0.81 ; P<0.01 ; I^{2}=71 \%\right)($ Figure 4$)$.

Time to first exacerbation was significantly longer in patients under single-inhaler triple therapy, compared with those on single-inhaler dual therapy (hazard radio, $0.86 ; 95 \% \mathrm{Cl} 0.84-0.89 ; P<0.01 ;\left.\right|^{2}=0 \%$ ) (Figure 4 ).

FEV1 (trough FEV1 compared to baseline value, $\mathrm{ml}$ ) increased significantly more under single-inhaler triple therapy obviously $(P<0.01)$ than in COPD patients treated by ICS/LABA (mean difference, 103.4 ML; 95\% Cl 64.65-142.15; $P<0.01 ; I^{2}=94 \%$ ) or LABA/LAMA (MD, 38.40 ML; 95\% Cl 7.05-69.75; $P<0.05 ; I^{2}=$ $86 \%$ ) (Figure 4).

Improvement in health-related quality of life (SGRQ total score) for single-inhaler triple therapy was statistically higher than with single-inhaler dual therapy. (MD, -1.48; 95\% Cl-1.75--1.22; $P<0.01 ; \mathrm{I}^{2}=0 \%$ ) (Figure 4).

\section{Safety endpoints}

Single-inhaler triple therapy was not associated with an increase in risk of adverse events (risk radio, $1.01 ; 95 \% \mathrm{Cl} 1.00-1.03 ; P \otimes 0.05 ; I^{2}=4 \%$ ) (Figure 5 ) or serious adverse events (RR, 0.97; 95\% $\mathrm{Cl} 0.93-1.02 ; P \otimes 0.05 ; I^{2}=0 \%$ ) when compared with single-inhaler dual therapy (Figure 5).

This was also the case for cardiovascular events (RR, 0.98; 95\% Cl 0.91-1.07; $P \otimes 0.05 ; 1^{2}=0 \%$ ) (Figure 5). Risk of pneumonia did not differ between ICS/LAMA/LABA and ICS/LABA (RR, 1.04; $\left.95 \% \mathrm{Cl} 0.87-1.23 ; P \otimes 0.05 ; I^{2}=36 \%\right)$, but use of ICS/LAMA/LABA was associated with a significant increase in the risk of pneumonia compared with LABA/LAMA (RR, 1.55; $95 \% \mathrm{Cl} 1.35-1.80 ; P \otimes 0.01 ; 1^{2}=0 \%$ ) (Figure 5).

\section{Discussion}

This systematic review aimed to investigate the long-term effects ( $\geq 24$ weeks) of single-inhaler triple therapy, compared with single-inhaler dual therapy for the treatment of COPD. Our results suggest that the ICS/LAMA/LABA combination was more effective in reducing all-cause mortality, risk of moderate or 
severe COPD exacerbations and prolonging time of first exacerbation than ICS/LABA or LABA/LAMA combinations. Furthermore, single-inhaler triple therapy had a significantly higher impact on both lung function (FEV1 trough) and health-related quality of life (HRQL: SGRQ score), compared to single-inhaler dual therapy. However, risk of pneumonia was significantly higher with ICS/LAMA/LABA than with LABA/LAMA.

Two recent meta-analyses showed that single-inhaler triple therapy was more effective in reducing acute exacerbations, and improving lung function and HRQL, compared with single-inhaler dual therapy.[20] [21] However, to the best of our knowledge, this meta-analysis is the first to show a reduction in all-cause mortality in stable COPD with fixed-dose triple therapy vs ICS/LABA or LABA/LAMA combinations.

The goal of COPD management is to decrease the risk of exacerbations and mortality.[1] Exacerbations are major determinants of patient's health status and strong predictors of mortality. [22] The present study concluded that, compared with single-inhaler dual therapy, single-inhaler triple therapy reduced the frequency of moderate and severe exacerbations by 22\%. In IMPACT [9] (FF/UMEC/VI vs. UMEC/VI) and ETHOS [19] (BUD/GLY/FOR (320- $\mu$ g- budesonide) vs. GLY/FOR) analyses, the risk of death from any cause was reduced by $29 \%$ and $46 \%$, respectively. The all-cause mortality reduction by ICS/LAMA/LABA may be due to the reduction in total exacerbations. In ETHOS [19] study, compared with GLY/FOR, BUD/GLY/FOR (320- $\mu$ g- budesonide) largely reduced the frequency of moderate and severe exacerbations by $24 \%$. IMPACT [9] study illustrated $25 \%$ of decrease in the rate of COPD exacerbations when comparing $\mathrm{FF} / \mathrm{UMEC} / \mathrm{VI}$ and UMEC/VI and $34 \%$ of reduction in COPD hospitalizations for this comparison. Perhaps, the decline in exacerbation events can improve patients' health and decrease the rate of hospitalization,[23] thus decreasing associated morbidity and mortality in COPD patients. However, some included RCTs did not display that single-inhaler triple therapy improved mortality compared with LABA/LAMA, partly due to the short follow-up period. Of these, the KRONOS[18] study was only of 24 weeks in duration, and it was limited in the reporting of such final health outcomes. It is also partly due to differences in the inclusion criteria of patients. In IMPACT [9] and ETHOS [19] studies, all-cause mortality exhibited a difference, which may be due to the high-risk nature of part of the included population experiencing cardiovascular events. In the 52 weeks TRIBUTE [8] study, the patients suffering from clinically significant cardiovascular disorders were excluded. Single-inhaler triple therapy may have direct or indirect effects on cardiovascular comorbidities in COPD patients, which possibly has been confirmed by the results before, suggesting that the risk of non-respiratory fatal events was significantly decreased with ICS/LAMA/LABA versus LABA/LAMA.[24]

Our findings suggest that single-inhaler triple therapy was statistically more effective than single-inhaler dual therapy in terms of lung function and quality of life. According to Jones 2013[25] and Bateman 2014[26], the consensus on the minimal clinically important differences (MCID) for trough FEV1 is 60mL, and, for SGRQ, 4 points of the total score. Thus, the benefit of single-inhaler triple therapy on trough FEV1 (81 ml) outweighed the MCID. This was not the case however for HRQL.

Patients under single-inhaler triple therapy showed a significant increase in risk of pneumonia vs. single-inhaler dual therapy. Results differed when comparing the two sub-groups. Risk of pneumonia was higher when taking ICS/LAMA/LABA than for the LABA/LAMA group: Differences were not significant when ICS/LAMA/LABA vs. ICS/LABA group. This confirms previous findings [20] [21]

The GOLD guidelines recommend that triple therapy be considered for the most severe COPD patients. [3] Patients using multiple devices are more likely to have an inappropriate inhalation technique. [12] Also, previous research has shown that COPD patients have a lower adherence to treatment persistence with multiple inhaler therapy than single-inhaler therapy.[27] [28] Single-inhaler therapy is simpler, and thus may lead to better compliance and improve clinical outcomes for COPD patients [29] and therefore decrease healthcare resource utilization. [11] [15] If these outcomes are achieved without increasing costs, this may reduce economic and healthcare resource burden.[14]

Our research has some limitations. Firstly, some of the included RCTs were performed over only 24 weeks, thus limiting their relevance for outcomes such as all-cause mortality. Secondly, both analyzed RCTs illustrated similar criteria for eligible patients, while with some differences, thus resulting in that patients suffer from different severity and complication. Further studies are needed to determine whether any specific subgroup of COPD patients is more likely to benefit from single-inhaler triple therapy. Finally, patients obtained dual or triple therapies at baseline; it is therefore unclear whether the abrupt discontinuation of previous medication could have contributed to our results.

In conclusion, our meta-analysis suggests a beneficial effect of single-inhaler triple therapy versus single-inhaler dual therapy in terms of mortality, frequency of moderate or severe COPD exacerbations, and lung function for symptomatic COPD patients. However, ICS/LAMA/LABA is associated with an increased risk of pneumonia when compared to a dual therapy of LABA/LAMA.

\section{Declarations}

\section{Author contributions:}

H. L. and H. X. completed the literature search, assessed the studies for inclusion eligibility, were directly involved in the data collection for the article, and did the statistical analysis. H. L. wrote the first draft of the article, in consultation with Y. G. and J. J. for data interpretation. All authors revised the report and approved the final version before submission. Y. G. had ultimately responsible for the decision of whether to submit for publication.

\section{References}

1. Global, regional, and national deaths, prevalence, disability-adjusted life years, and years lived with disability for chronic obstructive pulmonary disease and asthma, 1990-2015: a systematic analysis for the Global Burden of Disease Study 2015. Lancet Respir Med 2017, 5(9):691-706.

2. López-Campos JL, Tan W, Soriano JB: Global burden of COPD. Respirology 2016, 21(1):14-23. 
3. Global Initiative for Chronic Obstructive Lung Disease, " Global strategy for diagnosis, management, and prevention of COPD - 2020 Report; Available from: https://goldcopd.org/wp-content/uploads/2019/12/GOLD-2020-FINAL-ver1.2-03Dec19_WMV.pdf." (2020. [Last accessed 2020 Mar 7]. ).

4. Vestbo J, Papi A, Corradi M, Blazhko V, Montagna I, Francisco C, Cohuet G, Vezzoli S, Scuri M, Singh D: Single inhaler extrafine triple therapy versus longacting muscarinic antagonist therapy for chronic obstructive pulmonary disease (TRINITY): a double-blind, parallel group, randomised controlled trial. Lancet 2017, 389(10082):1919-1929.

5. Sousa AR, Riley JH, Church A, Zhu CQ, Punekar YS, Fahy WA: The effect of umeclidinium added to inhaled corticosteroid/long-acting $\beta 2$-agonist in patients with symptomatic COPD: a randomised, double-blind, parallel-group study. NPJ Prim Care Respir Med 2016, 26:16031.

6. Siler TM, Kerwin E, Sousa AR, Donald A, Ali R, Church A: Efficacy and safety of umeclidinium added to fluticasone furoate/vilanterol in chronic obstructive pulmonary disease: Results of two randomized studies. Respir Med 2015, 109(9):1155-1163.

7. Singh D, Papi A, Corradi M, Pavlišová I, Montagna I, Francisco C, Cohuet G, Vezzoli S, Scuri M, Vestbo J: Single inhaler triple therapy versus inhaled corticosteroid plus long-acting $\beta 2$-agonist therapy for chronic obstructive pulmonary disease (TRILOGY): a double-blind, parallel group, randomised controlled trial. Lancet 2016, 388(10048):963-973.

8. Papi A, Vestbo J, Fabbri L, Corradi M, Prunier H, Cohuet G, Guasconi A, Montagna I, Vezzoli S, Petruzzelli S et al: Extrafine inhaled triple therapy versus dual bronchodilator therapy in chronic obstructive pulmonary disease (TRIBUTE): a double-blind, parallel group, randomised controlled trial. Lancet 2018, 391(10125):1076-1084

9. Lipson DA, Barnhart F, Brealey N, Brooks J, Criner GJ, Day NC, Dransfield MT, Halpin DMG, Han MK, Jones CE et al: Once-Daily Single-Inhaler Triple versus Dual Therapy in Patients with COPD. N Engl J Med 2018, 378(18):1671-1680.

10. Lipson DA, Barnacle H, Birk R, Brealey N, Locantore N, Lomas DA, Ludwig-Sengpiel A, Mohindra R, Tabberer M, Zhu CQ et al: FULFIL Trial: Once-Daily Triple Therapy for Patients with Chronic Obstructive Pulmonary Disease. Am J Respir Crit Care Med 2017, 196(4):438-446.

11. Gaduzo S, McGovern V, Roberts J, Scullion JE, Singh D: When to use single-inhaler triple therapy in COPD: a practical approach for primary care health care professionals. Int J Chron Obstruct Pulmon Dis 2019, 14:391-401.

12. Rootmensen GN, van Keimpema AR, Jansen HM, de Haan RJ: Predictors of incorrect inhalation technique in patients with asthma or COPD: a study using a validated videotaped scoring method. J Aerosol Med Pulm Drug Deliv 2010, 23(5):323-328.

13. Mäkelä MJ, Backer V, Hedegaard M, Larsson K: Adherence to inhaled therapies, health outcomes and costs in patients with asthma and COPD. Respir Med 2013, 107(10):1481-1490.

14. Ismaila AS, Birk R, Shah D, Zhang S, Brealey N, Risebrough NA, Tabberer M, Zhu CQ, Lipson DA: Once-Daily Triple Therapy in Patients with Advanced COPD: Healthcare Resource Utilization Data and Associated Costs from the FULFIL Trial. Adv Ther 2017, 34(9):2163-2172.

15. Zhang S, King D, Rosen VM, Ismaila AS: Impact of Single Combination Inhaler versus Multiple Inhalers to Deliver the Same Medications for Patients with Asthma or COPD: A Systematic Literature Review. Int J Chron Obstruct Pulmon Dis 2020, 15:417-438.

16. Liberati A, Altman DG, Tetzlaff J, Mulrow C, Gøtzsche PC, loannidis JP, Clarke M, Devereaux PJ, Kleijnen J, Moher D: The PRISMA statement for reporting systematic reviews and meta-analyses of studies that evaluate health care interventions: explanation and elaboration. PLoS Med 2009, 6(7):e1000100.

17. Schardt C, Adams MB, Owens T, Keitz S, Fontelo P: Utilization of the PICO framework to improve searching PubMed for clinical questions. BMC Med Inform Decis Mak 2007, 7:16.

18. Ferguson GT, Rabe KF, Martinez FJ, Fabbri LM, Wang C, Ichinose M, Bourne E, Ballal S, Darken P, DeAngelis K et al: Triple therapy with budesonide/glycopyrrolate/formoterol fumarate with co-suspension delivery technology versus dual therapies in chronic obstructive pulmonary disease (KRONOS): a double-blind, parallel-group, multicentre, phase 3 randomised controlled trial. Lancet Respir Med 2018, 6(10):747-758.

19. Rabe KF, Martinez FJ, Ferguson GT, Wang C, Singh D, Wedzicha JA, Trivedi R, St Rose E, Ballal S, McLaren J et al: Triple Inhaled Therapy at Two Glucocorticoid Doses in Moderate-to-Very-Severe COPD. N Engl J Med 2020, 383(1):35-48.

20. Calzetta L, Ritondo BL, de Marco P, Cazzola M, Rogliani P: Evaluating triple ICS/LABALAMA therapies for COPD patients: a network meta-analysis of ETHOS, KRONOS, IMPACT, and TRILOGY studies. Expert Rev Respir Med 2020:1-10.

21. Lai CC, Chen $\mathrm{CH}$, Lin $\mathrm{CYH}$, Wang $\mathrm{CY}$, Wang YH: The effects of single inhaler triple therapy vs single inhaler dual therapy or separate triple therapy for the management of chronic obstructive pulmonary disease: a systematic review and meta-analysis of randomized controlled trials. Int $\mathrm{J}$ Chron Obstruct Pulmon Dis 2019, 14:1539-1548.

22. Boeck L, Soriano JB, Brusse-Keizer M, Blasi F, Kostikas K, Boersma W, Milenkovic B, Louis R, Lacoma A, Djamin R et al: Prognostic assessment in CoPD without lung function: the B-AE-D indices. Eur Respir J 2016, 47(6):1635-1644.

23. Lipson DA, Crim C, Criner GJ, Day NC, Dransfield MT, Halpin DMG, Han MK, Jones CE, Kilbride S, Lange P et al: Reduction in All-Cause Mortality with Fluticasone Furoate/Umeclidinium/Vilanterol in Patients with Chronic Obstructive Pulmonary Disease. Am J Respir Crit Care Med 2020, 201(12):15081516.

24. Vestbo J, Fabbri L, Papi A, Petruzzelli S, Scuri M, Guasconi A, Vezzoli S, Singh D: Inhaled corticosteroid containing combinations and mortality in CoPD. Eur Respir J 2018, 52(6).

25. Jones PW, Beeh KM, Chapman KR, Decramer M, Mahler DA, Wedzicha JA: Minimal clinically important differences in pharmacological trials. Am J Respir Crit Care Med 2014, 189(3):250-255.

26. Bateman E: Lack of clinically relevant differences between combination therapy and monotherapy in COPD. Eur Respir J 2014, 43(4):1204-1205.

27. Bogart M, Stanford RH, Laliberté F, Germain G, Wu JW, Duh MS: Medication adherence and persistence in chronic obstructive pulmonary disease patients receiving triple therapy in a USA commercially insured population. Int J Chron Obstruct Pulmon Dis 2019, 14:343-352. 
28. Yu AP, Guérin A, Ponce de Leon D, Ramakrishnan K, Wu EQ, Mocarski M, Blum S, Setyawan J: Therapy persistence and adherence in patients with chronic obstructive pulmonary disease: multiple versus single long-acting maintenance inhalers. J Med Econ 2011, 14(4):486-496.

29. Miravitlles M, Marín A, Huerta A, Carcedo D, Villacampa A, Puig-Junoy J: Estimation of the Clinical and Economic Impact of an Improvement in Adherence Based on the Use of Once-Daily Single-Inhaler Triple Therapy in Patients with COPD. Int J Chron Obstruct Pulmon Dis 2020, 15:1643-1654.

\section{Figures}

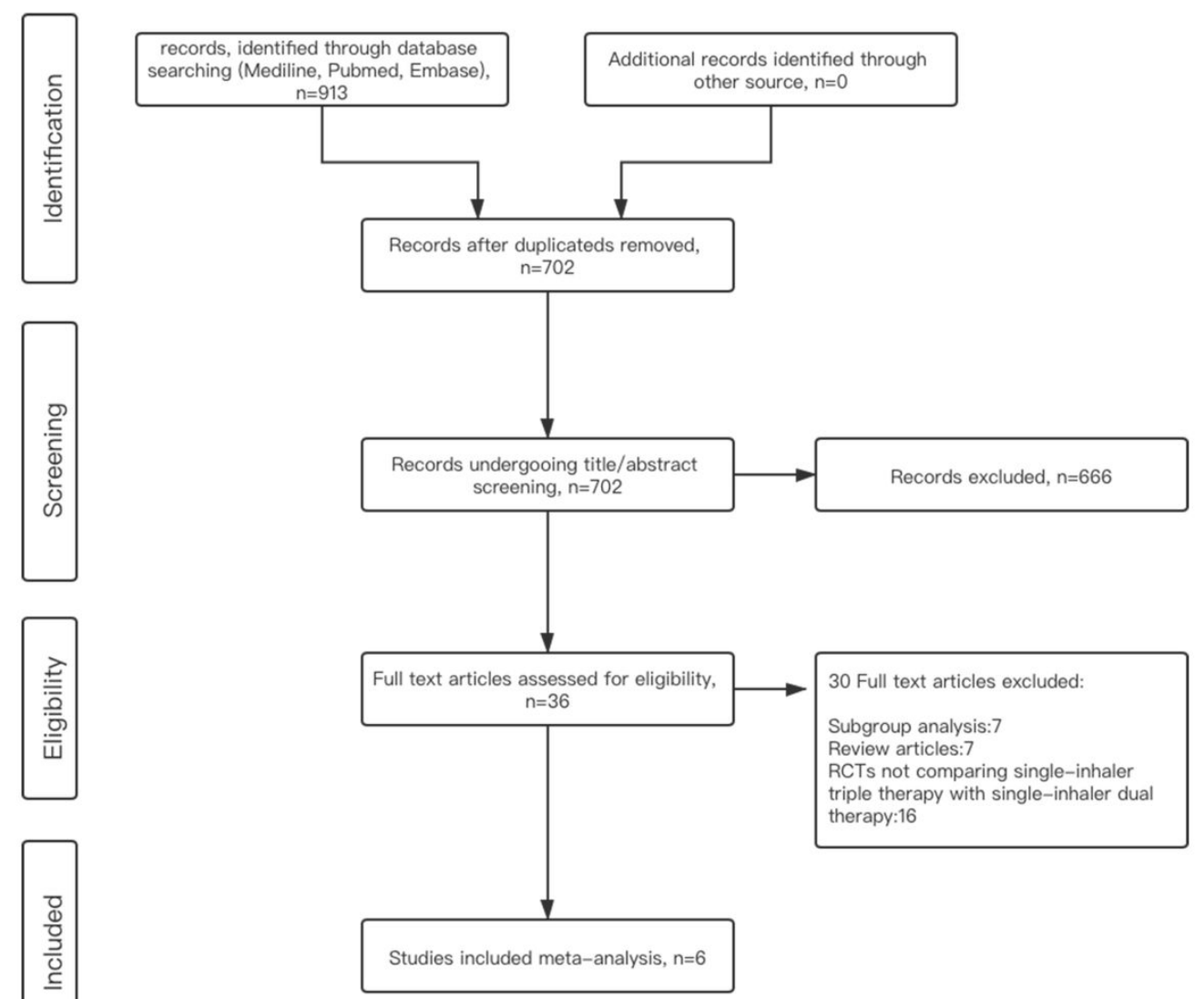

Figure 1

The flow diagram of the study selection process 


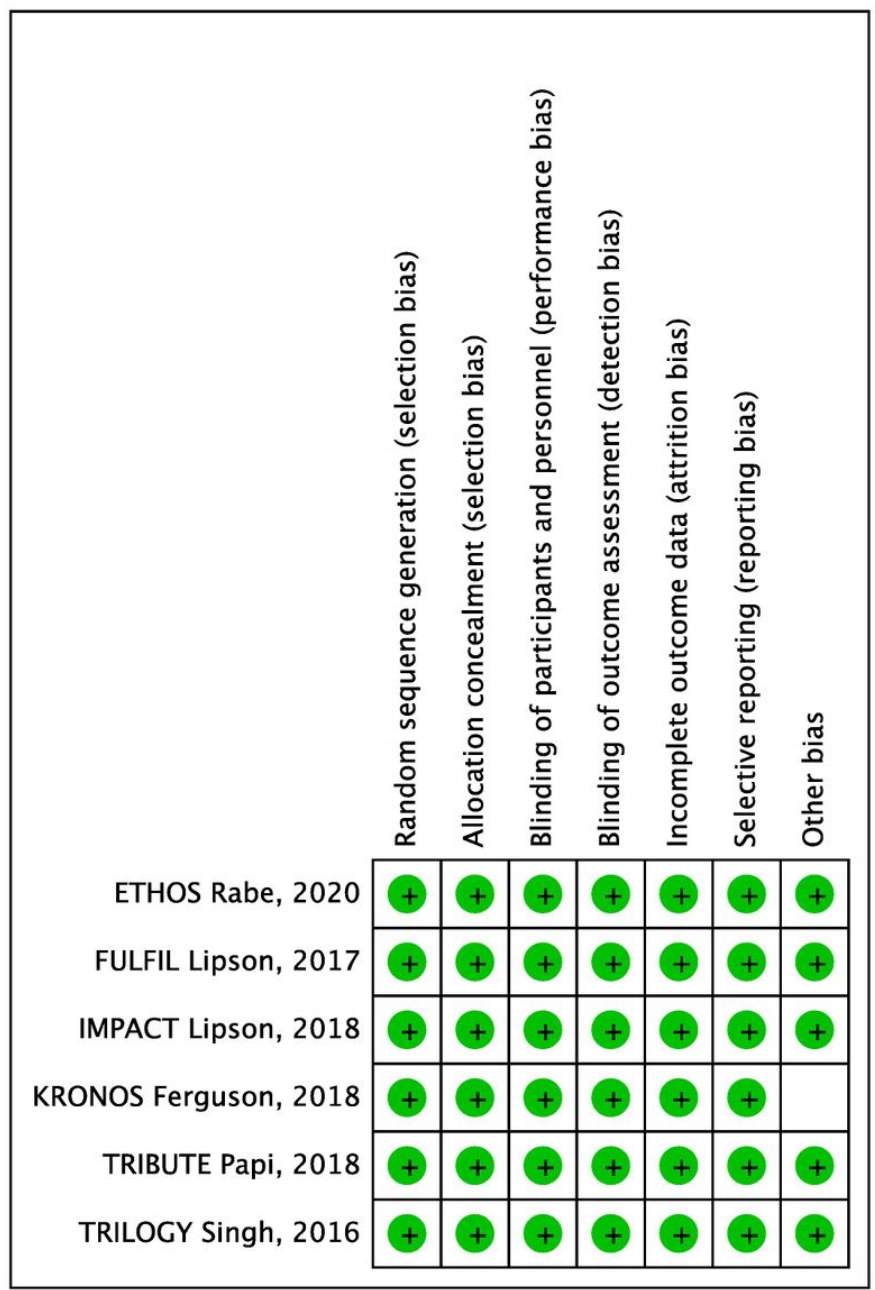

Figure 2

Risk of bias for studies 
a)

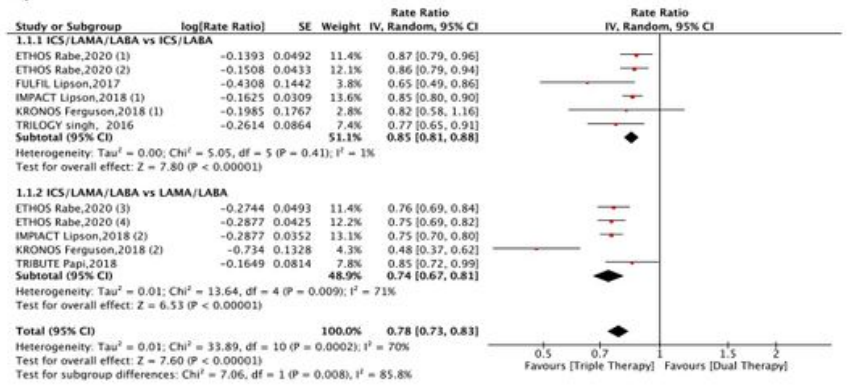

c)

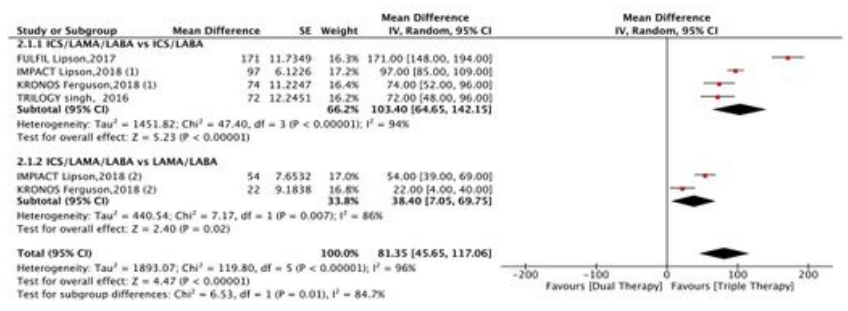

b)

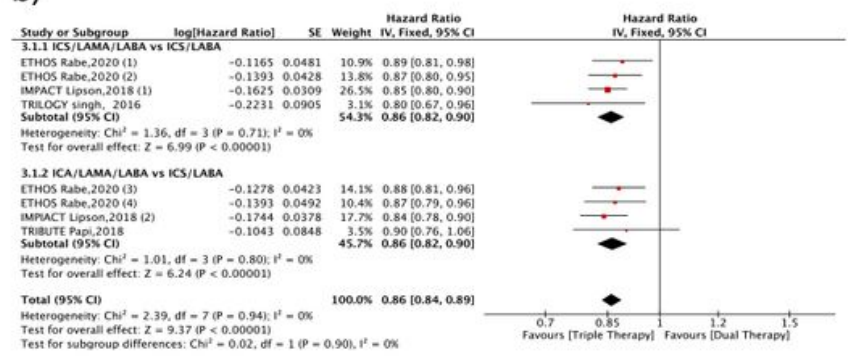

d)

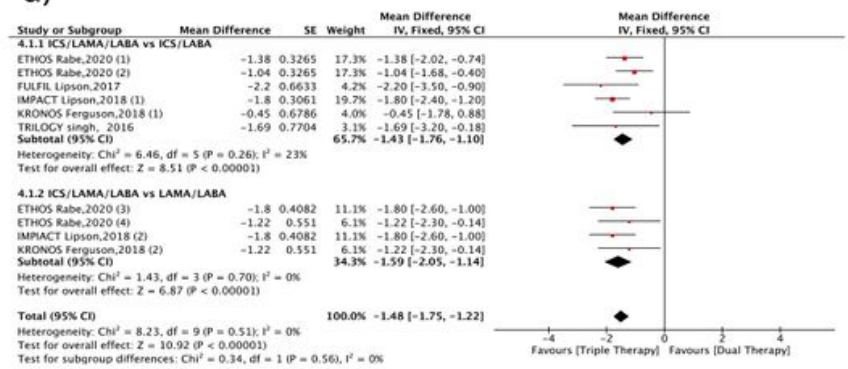

Figure 3

Efficacy endpoints

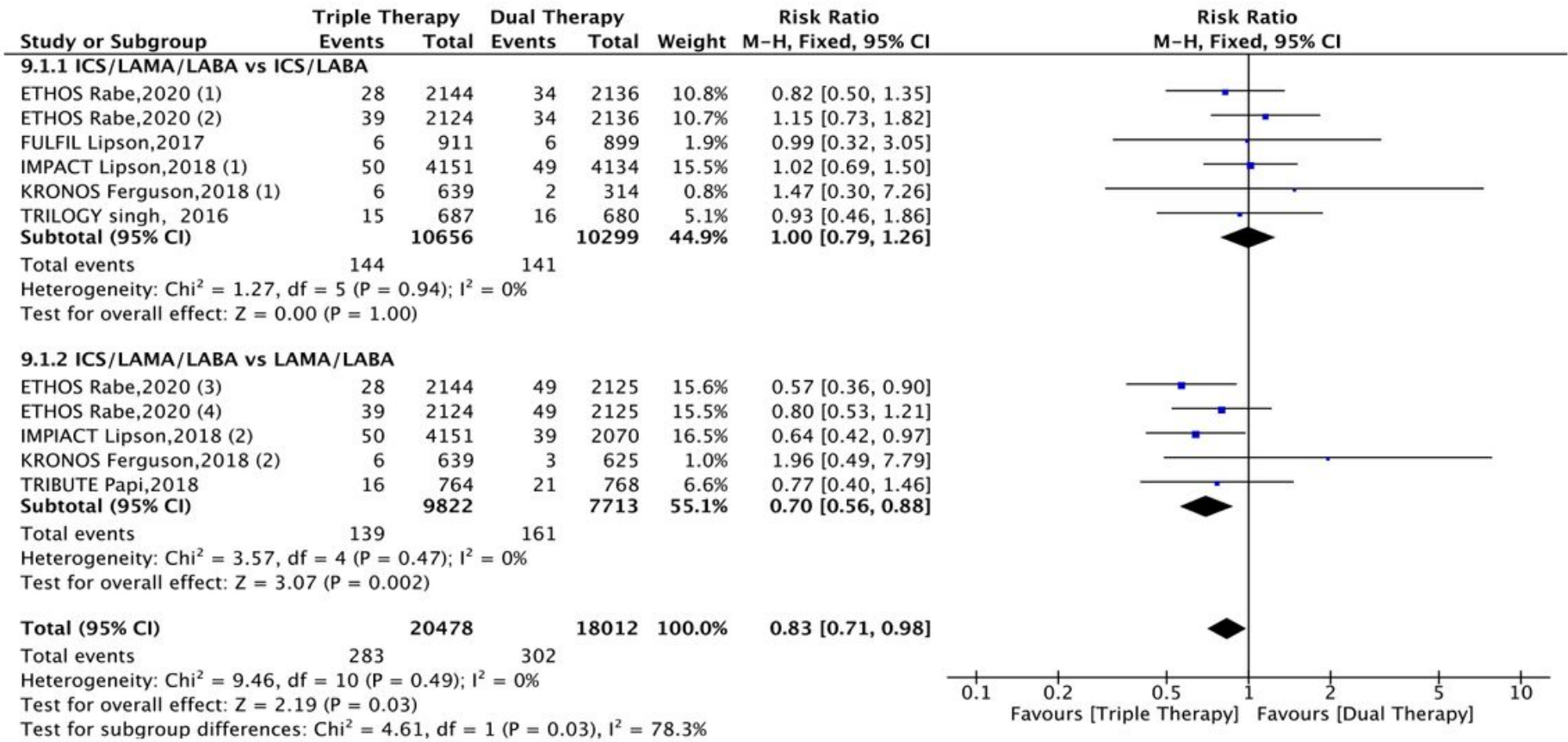

Figure 4

All cause mortality 
a)

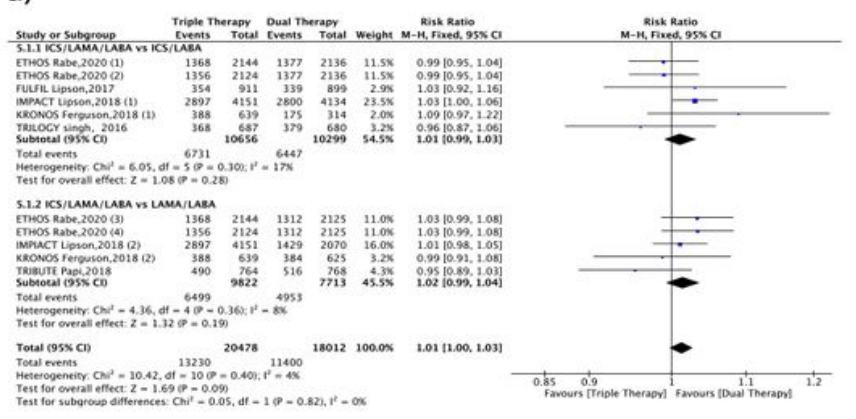

c)

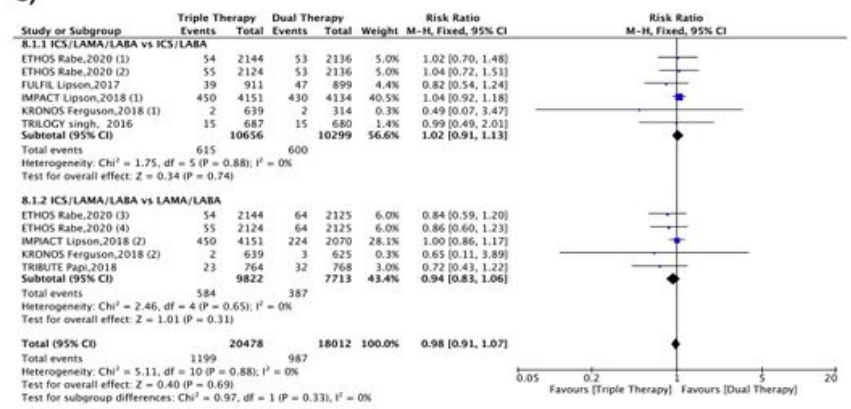

b)

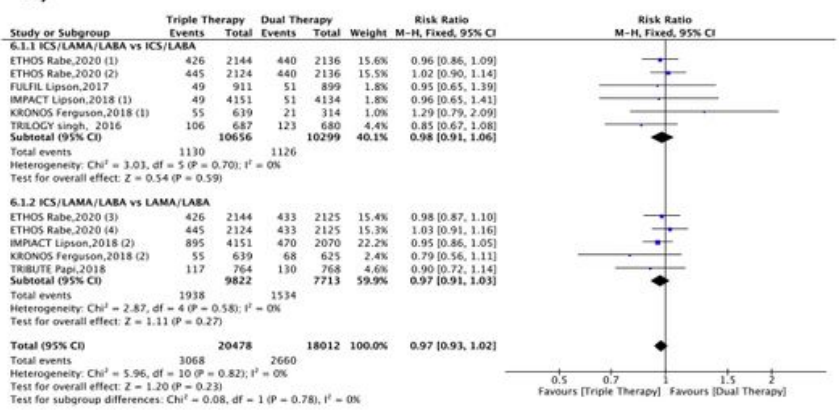

d)

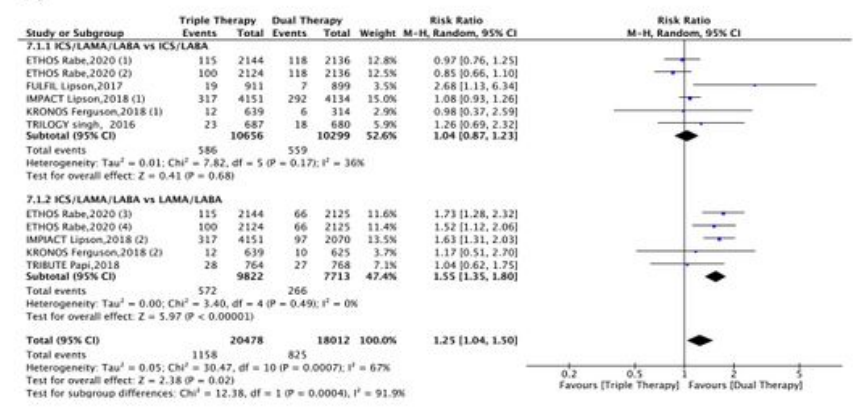

Figure 5

Safety endpoints 